Article - Agriculture, Agribusiness and Biotechnology

\title{
Serological and Molecular Detection of Latent Viruses in the Apple Germplasm Bank of Santa Catarina
}

\author{
Danielle Caroline Manenti ${ }^{1}$ \\ https://orcid.org/0000-0003-1043-7196
}

Maraisa Crestani Hawerroth ${ }^{2}$

https://orcid.org/0000-0002-5428-0744

Thyana Lays Brancher ${ }^{2}$

https://orcid.org/0000-0003-3337-6314

\section{Filipe Schmidt Schuh ${ }^{1}$}

https://orcid.org/0000-0002-6113-8893

\author{
Marcus Vinicius Kvitschal ${ }^{2}$ \\ https://orcid.org/0000-0001-6161-3546 \\ Osmar Nickel ${ }^{3}$ \\ https://orcid.org/0000-0002-7969-648X \\ Eliezer Rodrigues de Souto ${ }^{1^{*}}$ \\ https://orcid.org/0000-0001-5130-9671
}

1'State University of Maringá, Agronomy Department, Maringá, Paraná, Brazil; '2Epagri, Experimental Station of Caçador, Caçador, Santa Catarina, Brazil; ${ }^{3}$ Embrapa Grape and Wine, Bento Gonçalves, Rio Grande do Sul, Brazil

Received: 2019.04.30; Accepted: 2020.03.30.

*Correspondence: ersouto@uem.br; Tel.: +55-44-3011-3892 (E.R.S)

HIGHLIGHTS

- $\quad$ RT-PCR, DAS-ELISA and IC-RT-PCR reveals ASGV, ASPV and ACLS latent mixed infection in accessions of the Apple Germplasm Bank of Epagri.

\begin{abstract}
The Apple Germplasm Bank (AGB) of Santa Catarina Agricultural Research and Rural Extension Company - Epagri, AGB-Epagri, is the largest of the genus Malus in Brazil. Twenty-eight main accessions of this bank were virus screened through DAS-ELISA, RT-PCR and IC-RT-PCR during two consecutive reproductive cycles, and each accession showed latent mixed infection by at least two species, among ASGV, ASPV and ACLSV. The combined use of diagnostic methods helped overcome inconsistencies commonly found in apple virus detection and was shown essential for the AGB-Epagri can be safely used as a source of genetic variability and for the exchange of virus-free propagative material.
\end{abstract}

Keywords: apple stem grooving virus (ASGV); apple stem pitting virus (ASPV); apple chlorotic leaf spot virus (ACLSV); Malus spp.

\section{INTRODUCTION}

The AGB-Epagri has 387 accessions belonging to different Malus species. It is an old collection kept in the field, what prone it to phytosanitary problems arising, such as Botryosphaeria obtusa cankers, Venturia inaequalis and Colletotrichum gloesporioides leaf spots. Moreover, viruses are suspected to be associated with decline and reduced survival of grafted plants. More than 20 virus and viroid species are reported in apple, among then, Apple stem grooving virus (ASGV, genus Capillovirus), Apple stem pitting virus (ASPV, genus Foveavirus), Apple chlorotic leaf spot virus (ACLSV, genus Trichovirus) and Apple mosaic virus (ApMV, genus llarvirus) [1]. The ApMV was previously detected by DAS-ELISA in some accessions of AGBEpagri causing yellowish leaf spots. However, latent infections of other species were suspected.

Multiple virus infections result in death, plant predisposition to other pathogens, sharp drop in production, and low quality of fruits $[2,3,4,5]$. Less aggressive infections of latent viruses probably interfere in phenotype 
evaluation, like is being experienced in the breeding program for Glomerella leaf spot resistance carried out at Epagri.

Considering the AGB-Epagri is an important repository for germplasm exchanges, this work aimed to evaluate the 28 main accessions of this bank for ASGV, ASPV and ACLSV infection. These latent viruses are commonly associated with apple diseases all over the world.

\section{MATERIAL AND METHODS}

One plant per accession of AGB-Epagri was tested from non-fully expanded apical leaves of grown plants in the spring of the years 2015 and 2016. Accessions were selected based on their simultaneous resistance to apple scab (Venturia inaequalis) [6] and Glomerella leaf spot (Colletotrichum spp.) [7]. For double antibody sandwich-enzyme-linked immunosorbent assays (DAS-ELISA), plant extracts were prepared in $20 \mathrm{~mL} \cdot \mathrm{g}^{-1}$ of extraction buffer $(137 \mathrm{mM} \mathrm{CaCl}, 3 \mathrm{mM} \mathrm{KCl}, 2 \%$ PVP K25, 0.05\% Tween 20, and $0,02 \% \mathrm{NaN}_{3}$ ). Each accession was tested with purified specific antibodies (Bioreba®) for ASGV, ASPV and ACLSV in three replicates. Samples with absorbance readings at $405 \mathrm{~nm}$ equal to or greater than twice values of the negative readings were considered positives. Total RNA from leaves was extracted by adsorption on silica [8]. For cDNA synthesis in microcentrifuge tubes, $4 \mu \mathrm{L}$ of total RNA from each accession, $5 \mu \mathrm{L}$ of DEPC water and $1 \mu \mathrm{L}$ of antisense primer $(0,4 \mu \mathrm{M})$ were added. Samples were incubated at $80{ }^{\circ} \mathrm{C}$ for $2 \mathrm{~min}$ and on ice for $3 \mathrm{~min}$, following addition of $5 \mu \mathrm{L}$ of $5 x \mathrm{M}-\mathrm{MLV}$ reverse transcriptase buffer (Ludwig $\AA$ ), $1 \mu \mathrm{L}$ dNTPs (2,5 mM each), 0,7 $\mu \mathrm{L}$ RNase inhibitor (Invitrogen $\AA, 40 \mathrm{U} . \mu \mathrm{L}^{-1}$ ), $1 \mu \mathrm{L}$ of reverse transcriptase $\mathrm{M}$ MLV (Ludwig® ${ }^{\circledR}, 200 \mathrm{U}$ ) and $7,3 \mu \mathrm{L}$ of DEPC water for $1 \mathrm{~h}$ incubation at $37^{\circ} \mathrm{C}$. PCR samples were prepared to a final volume of $15 \mu \mathrm{L}$ by adding $1,5 \mu \mathrm{L}$ of $5 x$ Taq DNA polymerase buffer (Ludwig®), 0,6 $\mu \mathrm{L} \mathrm{MgCl} 2(25$ $\mathrm{mM}), 0,3 \mu \mathrm{L}$ dNTPs $(2,5 \mu \mathrm{M}$ each), 1,5 $\mu \mathrm{L}$ of sense and antisense primers $(10 \mu \mathrm{M}), 0,2 \mu \mathrm{LTaq}$ DNA polymerase (Ludwig ${ }^{\circledR}, 5 \cup \cdot \mu \mathrm{L}^{-1}$ ), $5 \mu \mathrm{L}$ cDNA and 4,4 $\mu \mathrm{L}$ DEPC water, subjected to amplification conditions of each primer (Table 1). Components of blank control consisted of all reagents except the RNA from plants.

Table 1. Primers for ASGV, ACLSV and ASPV detection in 28 accessions of Apple Germplasm Bank-Epagri.

\begin{tabular}{|c|c|c|c|c|}
\hline Primer name & Sequence (5' - 3') & $\begin{array}{l}\text { Position in } \\
\text { genome }\end{array}$ & $\begin{array}{l}\text { Fragment } \\
\text { size }\end{array}$ & $\begin{array}{l}\text { Annealing } \\
\text { temperature }\end{array}$ \\
\hline $\begin{array}{l}\text { ASGV } 6396 r \\
\text { ASGV } 5873 \mathrm{f}\end{array}$ & $\begin{array}{l}\text { CTG CAA GAC CGC GAC CAA GTT T } \\
\text { CCC GTC GTT GGA TTT GAT ACA CCT C }\end{array}$ & $\begin{array}{l}6373-6396 \\
5873-5898\end{array}$ & $524 \mathrm{bp}^{9}$ & $60^{\circ} \mathrm{C}$ \\
\hline ASGV $6396 r$ & CTG CAA GAC CGC GAC CAA GTT T & $6373-6396$ & & \\
\hline ASGV $5641 \mathrm{f}$ & ATG AGT TTG GAA GAC GTG CTT C & $5641-5663$ & $755 b p^{10}$ & $54^{\circ} \mathrm{C}$ \\
\hline ACLSV $7233 r$ & CAG ACC CTT ATT GAA GTC GAA & $7213-7233$ & $358 b p^{11}$ & $54^{\circ} \mathrm{C}$ \\
\hline ACLSV $6875 \mathrm{f}$ & GGC AAC CCT GGA ACA GA & $6875-6891$ & $358 \mathrm{Dp}$ & $54^{\circ} \mathrm{C}$ \\
\hline ACLSV $7365 r$ & CTA AAT GCA AAG ATC AGT CGA C & $7343-7365$ & & \\
\hline ACLSV $6784 \mathrm{f}$ & ATG GCA GCA GTT CTG AAT TTG & $6784-6805$ & $581 \mathrm{bp}^{2}$ & $55^{\circ} \mathrm{C}$ \\
\hline ASPV $3770 \mathrm{r}$ & GTC AGG TCA AAG ATG CTG AAA & $3750-3770$ & & \\
\hline ASPV $3480 \mathrm{f}$ & AGC GGT TGC CTA TTT TTG CTC C & $3480-3501$ & $291 b p^{12}$ & $50^{\circ} \mathrm{C}$ \\
\hline ASPV $9262 \mathrm{r}$ & ATA GCC GCC CCG GTT AGG TT & $3750-3770$ & & \\
\hline ASPV $8993 \mathrm{f}$ & CTC TTG AAC CAG CTG ATG GC & $3480-3501$ & $p^{12}$ & 5 \\
\hline
\end{tabular}

[Ref. 9], [Ref. 10], [Ref. 11], [Ref. 2], [Ref. 12], f- forward, $r$ - reverse.

For immunocapture reverse transcription (IC-RT)-PCR leaves were ground in liquid nitrogen and after in nucleoprotein extraction buffer (Bioreba $\left.{ }^{\circledR}\right)$, in $5 \mathrm{~mL} / 500 \mathrm{mg}$ proportion. Cultivar SCS417 Monalisa simultaneously infected by ASGV, ASPV and ACLSV was used as positive control (Table 2 and 3 ). Antibodies for each virus were $1: 1000$ diluted $(200 \mu \mathrm{L})$ and incubated in PCR tubes $(0,2 \mathrm{~mL})$ during $4 \mathrm{~h}$ at $37^{\circ} \mathrm{C}$. After PBS-Tween washes and addition of leaf extracts $(200 \mu \mathrm{L}), 25 \mu \mathrm{L}$ of the commercial mix (Qiagen® One Step RT-PCR Kit) were used as previously in the RT-PCR with same described primers (Table 1).

\section{RESULTS AND DISCUSSION}

The ASGV was detected by DAS-Elisa in 23 out of 28 accessions in the reproductive cycle of 2015, and in 18 genotypes of the 2016 cycle. Through molecular methods, detection in year 2015 was only with primers for amplification of 755 bp by IC-RT-PCR, in 23 accessions. Evaluation results of 16 accessions are shown (Fig 1A). For reproductive cycle of 2016, only RT-PCR gave amplifications of 755 and $524 \mathrm{bp}$, confirming the ASGV infection in respective 25 and 24 accessions. In serological and molecular detection, inconsistencies were observed (Tables 2 and 3). As in DAS-Elisa tests, ASGV was not detected in 'Baronesa' and 'Priscilla' also by PCR. A 755 bp amplification product from accession '21-502-1' was purified and sequenced at the Human Genome Research Center of the University of São Paulo. After alignment with GenBank sequences 
(https: //blast.ncbi.nlm.nih.gov/ Blast.cgi), the ASGV from AGB-Epagri was found $98 \%$ homolog with coat protein gene of accession LT574875 [13]. Variations in detection of ASGV were observed from year to year in accessions 'Co-op 14', 'Imperatriz', Malus floribunda, 'Nova Easygro' and 'Red Free' by DAS-ELISA tests, and in '21-261-75', 'Catarina' and 'Priam' by PCR (Tables 2 and 3).
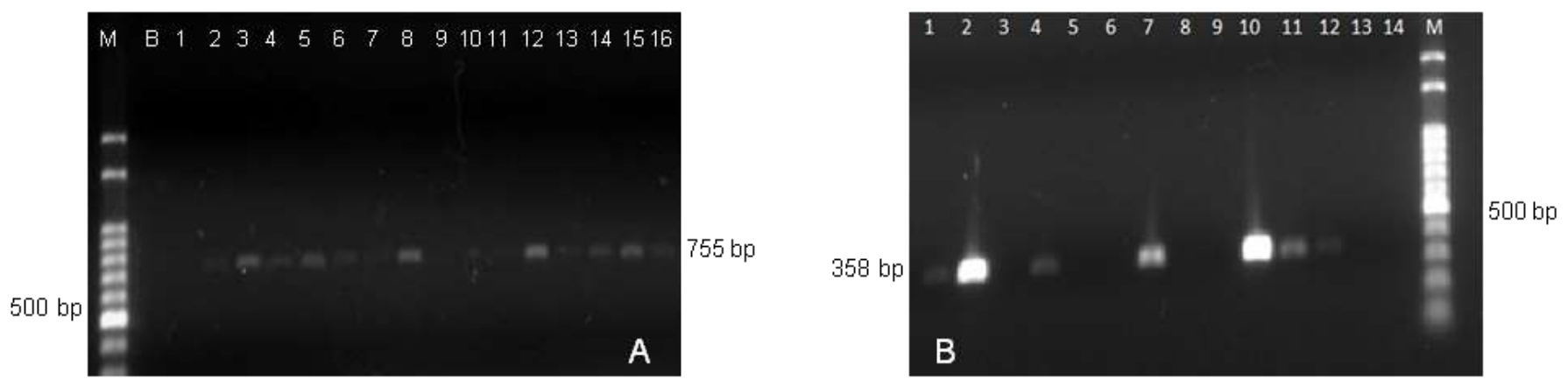

Figure 1. Electrophoresis in 1,2\% agarose gel of IC-RT-PCR $755 \mathrm{bp}$ amplifications of ASGV - A : M - 100 bp ladder (Ludwig®), B- blank; 1- '21-361-75'; 2 - '21-373-58'; 3 - '21-555-13'; 4 - '21-300-13'; 5 - '21-300-21'; 6 - '21-379-64'; 7 - '21-503-1'; 8 - 'Akane'; 9 - 'Baronesa'; 10 - 'Catarina'; 11 - 'Coop 14'; 12 - 'Coop 16'; 13 - 'Coop 24', 14 - 'Coop 8'; 15 - 'D1R102T116'; 16 - 'D1R103T245'. IC-RT-PCR 358 bp amplifications of ACLSV - B : M- 100 bp ladder (Ludwig()), 1 - 'Coop 24'; 2 - 'D1R102T116'; 3 - ‘D1R103T245'; 4 - 'Florina'; 5 - 'Fred Hough'; 6 - 'Imperatriz'; 7 'Liberty'; 8 - 'Mac Free'; 9 - Malus floribunda; 10 - 'Nova Easygro'; 11 - 'Priam'; 12 - 'Priscilla'; 13 - 'Red Free' e 14 'Sansa'.

Table 2. DAS-ELISA detection of ASGV, ASPV and ACLS in apples of the Germplasm Bank-Epagri during reproductive cycles of 2015 and 2016.

\begin{tabular}{|c|c|c|c|c|c|c|}
\hline \multirow{2}{*}{ Accession (Origin) } & \multicolumn{2}{|c|}{ ASGV } & \multicolumn{2}{|c|}{ ASPV } & \multicolumn{2}{|c|}{ ACLSV } \\
\hline & 2015 & 2016 & 2015 & 2016 & 2015 & 2016 \\
\hline 21-361-75 (Argentina) & $0,556(+)$ & $0,349(+)$ & $0,286(-)$ & $0,765(+)$ & $0,558(+)$ & $0,241(-)$ \\
\hline 21-373-58 (Argentina) & $0,951(+)$ & $0,457(+)$ & $0,348(-)$ & $0,521(+)$ & $0,387(+)$ & $0,335(-)$ \\
\hline 21-555-13 (Argentina) & $0,489(+)$ & $0,402(+)$ & $0,695(+)$ & $0,312(-)$ & $0,579(+)$ & $0,854(+)$ \\
\hline 21-300-13 (Argentina) & $0,576(+)$ & $0,421(+)$ & $0,795(+)$ & $0,688(+)$ & $0,309(-)$ & $0,347(-)$ \\
\hline 21-300-21(Argentina) & $1,616(+)$ & $0,627(+)$ & $0,620(+)$ & $0,496(+)$ & $0,976(+)$ & $3,062(+)$ \\
\hline 21-379-64 (Argentina) & $0,809(+)$ & $0,912(+)$ & $0,493(-)$ & $0,550(+)$ & $0,447(+)$ & $2,840(+)$ \\
\hline 21-502-1 (Argentina) & $1,156(+)$ & $0,746(+)$ & $0,915(+)$ & $0,634(+)$ & $1,219(+)$ & $1,984(+)$ \\
\hline Akane (Japan) & $0,975(+)$ & $0,460(+)$ & $0,498(-)$ & $0,765(+)$ & $0,836(+)$ & $0,248(-)$ \\
\hline Baronesa (Brazil/Epagri) & $0,203(-)$ & $0,181(-)$ & $0,300(-)$ & $0,742(+)$ & $0,295(-)$ & $0,192(-)$ \\
\hline Catarina (Brazil/Epagri) & $1,361(+)$ & $0,405(+)$ & $0,204(-)$ & $0,817(+)$ & $0,310(-)$ & $0,207(-)$ \\
\hline Co-op 8 (U.S) & $0,195(-)$ & $0,190(-)$ & $0,282(-)$ & $0,702(+)$ & $0,308(-)$ & $0,203(-)$ \\
\hline Co-op 14 (U.S) & $0,839(+)$ & $0,320(-)$ & $0,555(+)$ & $0,778(+)$ & $0,667(+)$ & $0,252(-)$ \\
\hline Co-op 16 (U.S) & $0,192(-)$ & $0,215(-)$ & $0,341(-)$ & $0,250(-)$ & $0,630(+)$ & $0,828(+)$ \\
\hline Co-op 24 (U.S) & $1,860(+)$ & $0,413(+)$ & $0,387(-)$ & $0,832(+)$ & $0,832(+)$ & $0,217(-)$ \\
\hline D1R102T116 (U.S) & $1,412(+)$ & $1,854(+)$ & $0,369(-)$ & $0,448(-)$ & $0,706(+)$ & $9,999(+)$ \\
\hline D1R103T245 (U.S) & $1,185(+)$ & $0,595(+)$ & $0,239(-)$ & $0,764(+)$ & $0,526(+)$ & $1,419(+)$ \\
\hline Florina (France) & $1,606(+)$ & $0,428(+)$ & $0,547(+)$ & $0,445(-)$ & $1,448(+)$ & $1,859(+)$ \\
\hline Fred Hough (Brazil/Epagri) & $1,302(+)$ & $0,582(+)$ & $0,269(-)$ & $0,880(+)$ & $0,457(+)$ & $0,424(+)$ \\
\hline Imperatriz (Brazil/Epagri) & $0,860(+)$ & $0,243(-)$ & $0,261(-)$ & $1,372(+)$ & $0,441(+)$ & $0,199(-)$ \\
\hline Liberty (U.S) & $0,885(+)$ & $0,402(+)$ & $0,323(-)$ & $0,467(+)$ & $0,777(+)$ & $1,421(+)$ \\
\hline Mac Free (U.S) & $0,694(+)$ & $0,366(+)$ & $0,470(-)$ & $0,856(+)$ & $0,647(+)$ & $0,225(-)$ \\
\hline Malus floribunda (Japan) & $0,449(+)$ & $0,206(-)$ & $0,570(+)$ & $0,453(-)$ & $0,542(+)$ & $0,267(-)$ \\
\hline Nova Easygro (Canada) & $0,756(+)$ & $0,321(-)$ & $1,153(+)$ & $0,991(+)$ & $0,803(+)$ & $0,467(+)$ \\
\hline Priam (U.S) & $0,189(-)$ & $0,196(-)$ & $0,244(-)$ & $0,459(+)$ & $0,513(+)$ & $9,999(+)$ \\
\hline Priscilla (U.S) & $0,182(-)$ & $0,171(-)$ & $0,321(-)$ & $0,828(+)$ & $0,849(+)$ & $0,509(+)$ \\
\hline Red Free (U.S) & $0,786(+)$ & $0,311(-)$ & $0,457(-)$ & $0,711(+)$ & $0,755(+)$ & $0,533(+)$ \\
\hline Sansa (Japan) & $1,865(+)$ & $0,363(+)$ & $0,281(-)$ & $0,959(+)$ & $0,789(+)$ & $0,366(-)$ \\
\hline Monalisa (Brazil/Epagri) & $0,457(+)$ & $0,492(+)$ & $0,773(+)$ & $1,166(+)$ & $0,585(+)$ & $0,796(+)$ \\
\hline Negative Control (Bioreba ${ }^{\circledR}$ ) & 0,183 & 0,168 & 0,273 & 0,229 & 0,169 & 0,206 \\
\hline
\end{tabular}

Values in table correspond to the average of three readings in Abs $405 \mathrm{~nm} .(+)$ indicates positive reaction whose reading average was higher than twice the value of negative control; (-) indicates negative reaction. Readings were for $120 \mathrm{~min}$ after enzyme substrate addition. Blank control was not tested. 
Fluctuation in virus titer, the uneven distribution in apple tree, type of tissue, and seasonal variations, would explain virus detection inconsistencies from one year to the next [14]. Moreover, RT-PCR is prone to false negatives due to RNA degradation or inhibitors of the reverse transcriptase or polymerase [15].

The second latent virus, ASPV, was detected by DAS-ELISA in nine out of 28 accessions in the reproductive cycle of 2015, and in 23 accessions of 2016. In the IC-RT-PCR, amplifications of 269 bp were obtained for all 28 accessions, with primers ASPV 9262r and ASPV 8993f, for the reproductive cycle of 2015, and by RT-PCR in the reproductive cycle of 2016. However, results were negative for accessions '21-36175', 'Akane', 'Florina', M. floribunda, 'Priam', 'Red Free', 'Sansa' and 'Monalisa' (Table 3).

Third latent virus, ACLSV, was detected by DAS-Elisa in 24 and 15 accessions, respectively in 2015 and 2016. The 'Co-op 8' accession was identified as the only non-positive for ACLSV, based on molecular and serological performed tests (Table 2 and 3). Variations in detection occurred in accessions '21-361-75', '21373-58', 'Akane', 'Co-op 14', 'Co-op 24', 'Imperatriz', 'Mac Free', M. floribunda and 'Sansa'. On the other hand, in molecular tests, ACLSV was detected in 27 accessions (Table 2 and 3). Amplifications of 358 bp with primers ACLSV $7233 \mathrm{r}$ and ACLSV $6875 \mathrm{f}$ were obtained by IC-RT-PCR, in 15 and 16 accessions, of respective cycles of 2015 and 2016. Evaluation results of 14 accessions are shown (Fig 1B). However, with the same pair of primers, there was amplification by RT-PCR in 18 accessions of the 2016 cycle.

The ACLSV amplified RT-PCR product was $90 \%$ homolog to part of coat protein of isolate ACLSV from Greece (GenBank accession AM292923.1) [16]. With the second pair of primers, ACLSV 7365r and ACLSV $6784 f, 581$ bp amplifications were obtained in nine of the 28 accessions by RT-PCR, but only for reproductive cycle of 2016. These primers anneal in part of each, coat and movement protein genes. Among ACLSV isolates there is high homology in coat protein, and lower in the movement protein, probably correlating with the common inconsistencies in ACLSV detection [11].

Inconsistencies in detection of ASGV and ASPV were also noticed in the apple germplasm bank of Canada, assigned to virus title fluctuation [1,17]. In general, combined use of virus detection methods in woody plants is most recommended strategy. Escape or false negative and/or positive results intrinsic to each method, can be minimized [13,18,19]. Analysis of 28 accessions of AGB-Epagri showed latent infection by at least two virus species in each accession. This confirmed detection of mixed infections in traditional apple tree cultivars in southern Brazil [10]. There are no reports of insect vectors for ASGV, ASPV and ACLSV. Therefore, rootstocks of unknown sanitary conditions probably are the main factor associated with high rates of infection. Latent virus infection would lead to plant decline and death, depending on virus strain and cultivar susceptibility, primarily as observed in apples grafted on 'Marubakaido', the most common apple rootstock in Brazil associated with ASGV and ACLSV [2,10]. Occurrence of ASGV, ASPV and ACLSV in accessions of AGB-Epagri would not recommend them for germoplasm exchange. However, a clonal cleaning program, permanent viral certification, and progressive reintroduction of accessions, would make them feasible as planting material. 
Table 3. IC-RT-PCR and RT-PCR detection of ASGV, ASPV and ACLSV in apples of the Germplasm Bank-Epagri during reproductive cycles of 2015 and 2016.

\begin{tabular}{|c|c|c|c|c|c|c|c|c|c|c|}
\hline C & $\begin{array}{l}2015 \\
\text { ASGV }\end{array}$ & $\begin{array}{r}2016 \\
\text { ASGV }\end{array}$ & $\begin{array}{l}2016 \\
\text { ASGV }\end{array}$ & $\begin{array}{l}2015 \\
\text { ASPV }\end{array}$ & $\begin{array}{r}2016 \\
\text { ASPV }\end{array}$ & $\begin{array}{c}2016 \\
\text { ASPV }\end{array}$ & $\begin{array}{c}2015 \\
\text { ACLSV }\end{array}$ & $\begin{array}{c}2016 \\
\text { ACLSV }\end{array}$ & $\begin{array}{c}2016 \\
\text { ACLSV }\end{array}$ & $\begin{array}{c}2016 \\
\text { ACLSV }\end{array}$ \\
\hline \multirow[t]{2}{*}{ Accession } & $755 \mathrm{bp}$ & $755 \mathrm{bp}$ & $524 \mathrm{bp}$ & $269 \mathrm{bp}$ & $269 \mathrm{bp}$ & $291 \mathrm{bp}$ & $358 \mathrm{bp}$ & 358 bp & 581 bp & $581 \mathrm{bp}$ \\
\hline & $\mathrm{IC}^{*}$ & RT-PCR & $\begin{array}{l}\text { RT- } \\
\text { PCR }\end{array}$ & IC & $\begin{array}{l}\text { RT- } \\
\text { PCR }\end{array}$ & $\begin{array}{l}\text { RT- } \\
\text { PCR }\end{array}$ & IC & IC & $\begin{array}{l}\text { RT- } \\
\text { PCR }\end{array}$ & RT-PCR \\
\hline $21-361-75$ & $-{ }^{* *}$ & + & + & + & + & - & + & + & - & + \\
\hline $21-373-58$ & $+{ }^{* *}$ & + & + & + & + & + & + & + & - & - \\
\hline $21-555-13$ & + & + & + & + & + & + & + & + & - & + \\
\hline $21-300-13$ & + & + & + & + & + & + & - & - & + & + \\
\hline $21-300-21$ & + & + & + & + & + & + & - & - & + & - \\
\hline $21-379-64$ & + & + & + & + & + & + & + & + & - & + \\
\hline 21-503-1 & + & + & + & + & + & + & + & + & - & - \\
\hline Akane & + & + & + & + & + & - & - & + & + & - \\
\hline Baronesa & - & - & - & + & + & + & + & - & + & - \\
\hline Catarina & - & + & + & + & + & + & - & - & + & - \\
\hline Coop 8 & + & + & - & + & + & + & - & - & - & - \\
\hline Coop 14 & + & + & + & + & + & + & + & + & - & - \\
\hline Coop 16 & + & + & - & + & + & + & - & - & + & + \\
\hline Coop 24 & + & + & + & + & + & + & + & + & + & + \\
\hline D1R102T116 & + & + & + & + & + & + & + & + & + & - \\
\hline D1R103T245 & + & + & + & + & + & + & - & + & + & - \\
\hline Florina & + & + & + & + & + & - & + & + & - & - \\
\hline Fred Hough & + & + & + & + & + & + & - & - & + & - \\
\hline Imperatriz & + & + & + & + & + & + & - & - & + & - \\
\hline Liberty & + & + & + & + & + & + & + & + & - & - \\
\hline Mac Free & + & + & + & + & + & + & - & - & + & - \\
\hline $\begin{array}{l}\text { Malus } \\
\text { floribunda }\end{array}$ & + & + & + & + & + & - & - & + & - & + \\
\hline Nova Easygro & + & + & + & + & + & + & + & + & + & - \\
\hline Priam & - & - & + & + & + & - & + & + & + & - \\
\hline Priscilla & - & - & - & + & + & + & + & - & + & + \\
\hline Red Free & + & + & + & + & + & - & - & + & + & + \\
\hline Sansa & + & + & + & + & + & - & - & - & + & - \\
\hline Monalisa & + & + & + & + & + & _ & + & - & + & - \\
\hline
\end{tabular}

${ }^{\star}$ IC: immunocapture-RT-PCR. ${ }^{* \star}(-)$ : negative, no amplification of expected fragment. ${ }^{* \star *}(+)$ : positive, expected fragment amplification.

\section{CONCLUSION}

All the twenty-eight accessions of AGB-Epagri are infected by at least two of the main latent virus species that worldwide infect apple trees, ASGV, ASPV and ACLSV.

Funding: This research received funding from Santa Catarina State Research and Innovation Foundation-FAPESC, grant number 2015TR319.

Acknowledgments: Special thanks to Higher Education Improvement Coordination-CAPES and Brazilian National Council for Scientific and Technological Development-CNPq for scholarship concessions.

Conflicts of Interest: The authors declare no conflict of interest. The funders had no role in the design of the study; in the collection, analyses, or interpretation of data; in the writing of the manuscript, or in the decision to publish the results. 


\section{REFERENCES}

1. Wang LP, Hong N, Matić S, Myrta A, Song YS, Michelutti R, Wang GP. Pome fruit viruses at the Canadian Clonal Genebank and molecular characterization of Apple chlorotic leaf spot virus isolates. Sci Hort. 2011 Sep; 130 (3) 665 71.

2. Silva FN, Nickel O, Fajardo TVM, Bogo A. Indexação biológica múltipla e RT-PCR para detecção de vírus latentes em macieiras. Trop plant pathol. 2008 Mar; 33 (2)157-61.

3. Nickel O, Fajardo TVM. Obtenção de material propagativo livre de vírus e diagnóstico de vírus em macieiras e pereiras. Bento Gonçalves: Embrapa Uva e Vinho. 2009, 69, 54p.

4. Hadidi A, Barba M. Economic impact of pome and stone fruit viruses and viroids. In: Hadidi $A$, Barba M, Candresse T, Jelkmann W editors. Virus and virus like diseases of pome and stone fruits. St. Paul (MN): APS Press; $2011 ; 1-8$.

5. Guerra DS, Nickel O, Del Ponte EM, Sanhueza RMV, Fajardo TVM, Marodin GAB. Development of Glomerella leaf spot is enhanced in virus-infected Maxi Gala apples. J.Plant Pathol. 2012 Jan; 94(1) 237-41.

6. Schuh FS, Kvitschal MV, Denardi F, Vidigal Filho OS, Manenti DC, Hawerroth MC. Divergência genética e seleção de parentais para o Programa de Melhoramento Genético de Macieira da Epagri. In: XIV Encontro Nacional Sobre Fruticultura De Clima Temperado (Enfrute), Fraiburgo, SC. Anais Caçador-Epagri. 2015. p.162.

7. Furlan CRC, Dantas ACM, Denardi F, Becker WF, Mantovani A. Resistência genética dos acessos do banco de germoplasma de macieira da Epagri à mancha foliar de Glomerella (Colletotrichum gloesporioides). Rev Bras Frutic. 2010 Jun; 32 (2) 507-14.

8. Rott ME, Jelkmann W. Characterization and detection of several filamentous viruses of cherry: adaptation of an alternative cloning method (DOP-PCR), and modification of an RNA extraction protocol. Eur J Plant Pathol. 2001 May; 107 (4) 411-20.

9. Mackenzie D.J, Mclean MA, Mukerji S, Green M. Improved RNA extraction from woody plants for the detection of viral pathogens by reverse transcription-polymerase chain reaction. Plant Dis. 1996 Feb; 81(2) 222-26.

10. Nickel O, Fajardo TVM, Jelkmann W, Kuhn GB. Sequence analysis of the capsid protein gene of an isolate of Apple stem grooving virus and its survey in Southern Brazil. Fitopatol Bras. 2011 Sep; 26(3) 655-59.

11. Candresse T, Lanneau M, Revers F, Grasseau N, Macquaire G, German S, Malinowski T, Dunez J. An immunocapture PCR assay adapted to the detection and the analysis of the molecular variability of the Apple chlorotic leaf spot virus. Acta Hort. 1995 Jul; 386, 136-47.

12. Radaelli P, Nickel O, Schons J, Aragão IFJL, Fajardo TVM. Diagnóstico biológico e molecular e análise da sequência de nucleotídeos do gene da proteína capsidial de um isolado do Apple stem pitting virus. Fitopatol bras. 2006 Fev; 31(1) 51-6.

13. Grimová L, Winkowska L, Zíka L, Ryšánek P. Distribution of viruses in old commercial and abandoned orchads and wild apple trees. J Plant Pathol. 2016 Mar; 98(3) 549-54.

14. Menzel W, Zahn V, Maiss E. Multiplex RT-PCR-ELISA compared with bioassay for the detection of four apple viruses. J. Virol. Methods. 2003 May; 110 (2) 153-7.

15.Park H, Yoon J, Kim H, Baek K. Multiplex RT-PCR assay for the detection of Apple chlorotic grooving virus and Apple chlorotic leaf spot virus in infected Korean apple cultivars. Plant Pathol. J., 2006 Jun; 22 (2) 168-73.

16. Mathioudakis MM, Candresse T, Katis N. First report of Apple chlorotic leaf spot virus in Quince in Greece. Plant Dis. 2007 Mar; 91(4) 462.

17. Yu Y, Zhao Z, Jiang D, Wu Z, Li S. A one-step multiplex RT-PCR assay for simultaneous detection of four viruses that infect peach. Lett. Appl. Microbiol., 2013 Oct; 57, 350-55.

18. Myrta A, Di Terlizzi B, Stamo B, Al Wahnih M, Savino V, Carraro L. A preliminary account of the presence of pome fruit viruses in Albania. Acta Hort. 2003 Sep; 657, 55-8.

19. Caglayan K, Ulubas Serce C, Gazel M, Jelkmann W. Detection of four Apple viruses by ELISA and RT-PCR assays in Turkey. Turk J Agric For. 2006 Jan, 30 (4) 241-6.

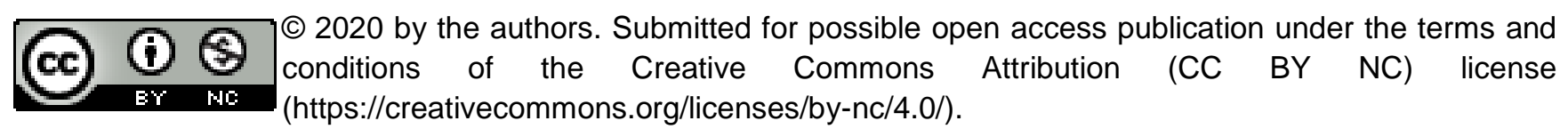

